\title{
Epidemiology of Parkinsonism and Parkinson's disease in Sub-Saharan Africa: Nigerian profile
}

Parkinsonism and Parkinson's disease (PD) are the most common movement disorders (neurological syndromes characterized by paucity of voluntary and automatic movements or excessive movements unrelated to muscle weakness or spasticity), and they are generally perceived to have lower prevalence and incidence in Sub-Saharan Africa (SSA) because of the relative youthfulness of the SSA population $(<5 \%$ are over 65 years of age), underrecognition, paucity of published reports, and cultural perception of neurologic disorders generally as being part of normal ageing. ${ }^{[1]}$

In Nigeria, Africa's most populous nation, the earliest detailed report on Parkinsonism and PD dates back to about 40 years ago when Osuntokun ${ }^{[2]}$ described extra pyramidal disorders in $1.9 \%$ of 9600 patients with neurological conditions seen over a 12 year period (1957-69) at the University College Hospital Ibadan, Southwestern Nigeria. Most subsequent reports on this syndrome from Nigeria have emanated similarly from the same region, the current report by Owolabi et al[ ${ }^{[3]}$ being the very first from the expansive northern region of the country.

In 1978, Osuntokun and Bademosi described 217 Nigerians with Parkinsonism, of whom $38 \%$ were classified as PD. ${ }^{[1,3,4]}$ However, in a recent 10 year review of Parkinsonism as seen in the major tertiary hospital in Lagos, the Nigerian commercial nerve center in the Southwest, $79 \%$ of the 124 patients reviewed had $\mathrm{PD}^{[4]}$ a figure very close to the $83 \%$ documented from the current review from Kano, Northern Nigeria. ${ }^{[3]}$ The increased proportion of PD is thought to be due to recent refinements in the diagnostic criteria for PD and Parkinsonism syndromes. ${ }^{[1]}$ The spectrum of secondary Parkinsonism and Parkinson-plus syndromes

\begin{tabular}{|l|l|}
\hline \multicolumn{2}{|c|}{ Access this article online } \\
\hline Quick Response Code: & Website: \\
\hline & www.ruralneuropractice.com \\
\cline { 2 - 3 } & \\
\hline & \\
\hline
\end{tabular}

documented from these hospital series and other anecdoctal reports in Nigeria includes Parkinsonism secondary to Wilson's disease, cerebral vascular disease, drugs, trauma, tumor excision, typhoid septicemia, and human immunodeficiency virus (HIV) infection. Others are multiple system atrophy, dementia with Lewy bodies, progressive supranuclear palsy, hemiparkinsonism-hemiatrophy, juvenile parkinsonism with dystonia and hemiatrophy and primary amyloidosis with parkinsonism. ${ }^{[1,3,4]}$

A pioneering epidemiologic survey of PD from a rural community in Southwestern Nigeria yielded an age-adjusted prevalence rate of 67 per 100,000 (above 39 years) ${ }^{[5]}$ while a case-control study on risk factors found blacksmithing (OR $8.095 \%$ CI 1.3- 50.7) ${ }^{[6]}$ to be significantly associated with PD. There are no data on exposure to pesticides, herbicides, rural living, and well water use. A preliminary analysis of the genetic contributions to PD in Nigerians explored the role of mutations in LRRK2, PRKN, and ATXN3 genes and found some novel but non-pathogenic mutations. ${ }^{[7]}$

Neuropathological studies involving brain tissue samples of neurologically normal Nigerians showed number of melanized neurons ${ }^{[8]}$ and Lewy body pathology burden ${ }^{[9]}$ similar to findings in Caucasian populations implying that the frequency of PD-related pre-symptomatic neuropathology (and indirectly the risk of PD) among Nigerian and Caucasian populations may be similar, but the effect of yet unidentified genetic factors, environmental exposures, differences in population structure and reduced life expectancy of Nigerians (about 50 years) may explain the differences in the prevalence and incidence rates observed between the two population groups.

Findings from this seminal work of Owolabi et al[3] reveal some shared features of PD in both Northern and Southern Nigeria. ${ }^{[2-4]}$ These include onset of disease in the sixth decade, male preponderance, under-diagnosis, late presentation, higher mortality, higher proportion of tremor dominant PD, and relatively low proportion of young onset and familial disease compared to Western 
populations. However, the relatively older age of onset in the current study ${ }^{[3]}$ compared to older studies ${ }^{[1,3,4]}$ may be a subtle evidence of ongoing epidemiologic transition.

Non-motor manifestations including cognitive dysfunction, autonomic dysfunction, psychiatric symptoms (especially apathy, depression, and anxiety), gastrointestinal and sudomotor disturbances all of which significantly impact patients' quality of life have also been described among Nigerian PD patients. ${ }^{[10,11]}$

The management of PD in Nigeria is fraught with challenges which include high cost and narrow spectrum of available treatment options and medications, paucity of movement disorders specialists, late presentation occasioned by poor public awareness and wrong cultural perceptions of the disease and high caregiver burden. ${ }^{[1,2,4]}$

Overall, though the current report ${ }^{[3]}$ represents an important milestone in the annals of movement disorders in Nigeria and SSA, there still exists knowledge gaps in several aspects including current prevalence and incidence, natural history, quality of life, cost of care, treatment outcomes and clinico-genetic-pathological correlations of PD and other movement disorders. Intraand international collaborations are needed to enhance research and capacity building while advocacy through public awareness campaigns and support groups will improve the recognition and adequate holistic treatment of Parkinsonism and PD in rural and urban SSA.

\section{Rufus O Akinyemi ${ }^{1,2}$ \\ ${ }^{1}$ Division of Neurology, Department of Medicine, Federal Medical Centre, Abeokuta, Nigeria, ${ }^{2}$ Institute for Ageing and Health, Newcastle University, Newcastle upon Tyne, NE4 5PL,UK.}

Address for correspondence: Dr. Rufus O Akinyemi, Division of Neurology, Department of Medicine, Federal Medical Centre, Abeokuta, Nigeria. E-mail: rufusakinyemi@yahoo.com

\section{References}

1. Akinyemi RO, Okubadejo NU. Movement Disorders in Africa: A review. Archives of Ibadan Medicine (Special Neurosciences Edition) 2010;10:58-64.

2. Osuntokun BO. The Pattern of Neurological Illness in Tropical Africa: Experience at Ibadan, Nigeria. J Neurol Sci 1971;12:417-42.

3. Owolabi LF, Ibrahim A, Aliyu S. Clinical profile of Parkinsonian disorders in the tropics: Experience at Kano, Northwestern Nigeria. J Neurosci Rural Pract 2012;3:237-41.

4. Okubadejo NU, Ojo OO, Oshinaike OO. Clinical profile of parkinsonism and Parkinson's disease in Lagos, Southwestern Nigeria. BMC Neurol 2010;10:1.

5. Schoenberg BS, Osuntokun BO, Adeuja AO, Bademosi O, Nottidge V, Anderson DW, et al. Comparison of the prevalence of Parkinson's disease in black populations in the rural United States and in rural Nigeria: Doorto-door community studies. Neurology 1988;38:645-6.

6. Falope ZF, Osuntokun BO, Ogunniyi AO. Risk factors for Parkinson's disease in Nigerians. A case control study. J Trop Geogr Neurol1992;2:177-80.

7. Njideka Okubadejo, Angela Britton, Cynthia Crews, Rufus Akinyemi, John Hardy, Andrew Singleton, Jose Bras. Analysis of Nigerians with Apparently Sporadic Parkinson Disease for Mutations in LRRK2, PRKN and ATXN3. PLoS One2008;3:e3421.

8. Muthane UB, Chickabasaviah YT, Henderson J, Kingsbury AE, Kilford L, Shankar SK, et al. Melanized nigral neuronal numbers in Nigerian and British individuals. Mov Disord 2006;21:1239-41.

9. Jendroska K, Olasode BJ, Daniel SE, Elliot L, Ogunniyi AO, Aghadiuno PU, et al. Incidental Lewy body disease in black Africans. Lancet 1994;344:1503.

10. Akinyemi RO, Okubadejo NU, Akinyemi JO, Owolabi MO, Owolabi LF, Ogunniyi A.Cognitive dysfunction in Nigerians with Parkinson's disease. Mov Disord 2008;23:1378-83.

11. Akinyemi RO, Okubadejo NU, Ogunniyi A. Non-motor manifestations in Nigerian patients with Parkinson's disease. 2011 World Congress of Neurology Marrakesh, Morocco: (Abstract 173).

How to cite this article: Akinyemi RO. Epidemiology of Parkinsonism and Parkinson's disease in Sub-Saharan Africa: Nigerian profile. J Neurosci Rural Pract 2012;3:233-4.

Source of Support: Nil. Conflict of Interest: None declared.

\section{“QUICK RESPONSE CODE" LINK FOR FULL TEXT ARTICLES}

The journal issue has a unique new feature for reaching to the journal's website without typing a single letter. Each article on its first page has a "Quick Response Code". Using any mobile or other hand-held device with camera and GPRS/other internet source, one can reach to the full text of that particular article on the journal's website. Start a QR-code reading software (see list of free applications from http://tinyurl.com/yzlh2tc) and point the camera to the QR-code printed in the journal. It will automatically take you to the HTML full text of that article. One can also use a desktop or laptop with web camera for similar functionality. See http://tinyurl.com/2bw7fn3 or http://tinyurl.com/3ysr3me for the free applications. 